\title{
Anti-Ma2-associated encephalitis in a patient with testis carcinoma
}

Figure $\quad$ MRI at presentation (A) and after clinical relapse (B)

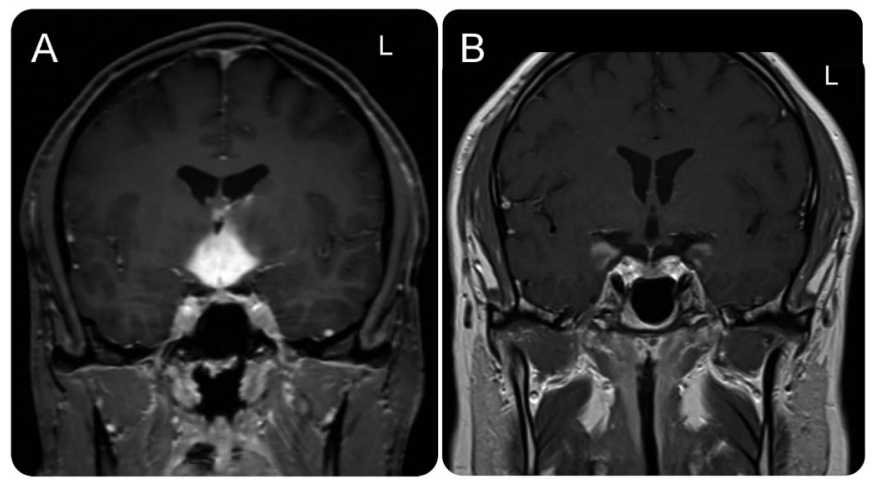

(A) T2-weighted hyperintensity of the hypothalamus with contrast enhancement. (B) T2-weighted hyperintensity of the hippocampus on both sides, more pronounced on the right side, with contrast enhancement.

A 30-year-old man presented with 3 months of alternating hyper- and hypothermia, libido loss, hypersomnia, and headache. Neurologic examination was unremarkable. Laboratory tests revealed low serum testosterone and hypocortisolism. MRI showed hypothalamic T2 hyperintensity and contrast enhancement (figure, A). CSF analysis showed moderate lymphocytosis. Cerebral infections and malignancies were excluded. Methylprednisolone was started based on a working-diagnosis of lymphocytic hypothalamitis. After initial improvement, the patient relapsed, with MRI showing limbic involvement (figure, B). Serum and CSF screening was positive for anti-MA2. Ultrasonography showed microcalcification of the right testicle, which was resected. Histology showed focal germ cell neoplasia.

Sven R. Suwijn, MD, Lars P. Klieverik, MD, Vincent J.J. Odekerken, MD

From the Departments of Neurology (S.R.S., V.J.J.O.) and Endocrinology and Metabolism (L.P.K.), Academic Medical Center, University of Amsterdam, the Netherlands.

Author contributions: S.R. Suwijn: draft of the manuscript. L.P. Klieverik: critical revision of the manuscript for important intellectual content. V.J.J. Odekerken: critical revision of the manuscript for important intellectual content.

Study funding: No targeted funding reported.

Disclosure: S. Suwijn and L. Klieverik report no disclosures relevant to the manuscript. V. Odekerken received a travel grant from Medtronic in 2014. Go to Neurology.org for full disclosures.

Correspondence to Dr. Suwijn: s.r.suwijn@amc.uva.nl 


\section{Neurology}

\section{Anti-Ma2-associated encephalitis in a patient with testis carcinoma \\ Sven R. Suwijn, Lars P. Klieverik and Vincent J.J. Odekerken \\ Neurology 2016;86;1461 \\ DOI 10.1212/WNL.0000000000002574}

\section{This information is current as of April 11, 2016}

Updated Information \&
Services

Subspecialty Collections

Permissions \& Licensing

Reprints including high resolution figures, can be found at: http://n.neurology.org/content/86/15/1461.full

This article, along with others on similar topics, appears in the following collection(s):

Encephalitis

http://n.neurology.org/cgi/collection/encephalitis

Paraneoplastic syndrome

http://n.neurology.org/cgi/collection/paraneoplastic_syndrome

Information about reproducing this article in parts (figures,tables) or in its entirety can be found online at:

http://www.neurology.org/about/about_the_journal\#permissions

Information about ordering reprints can be found online:

http://n.neurology.org/subscribers/advertise

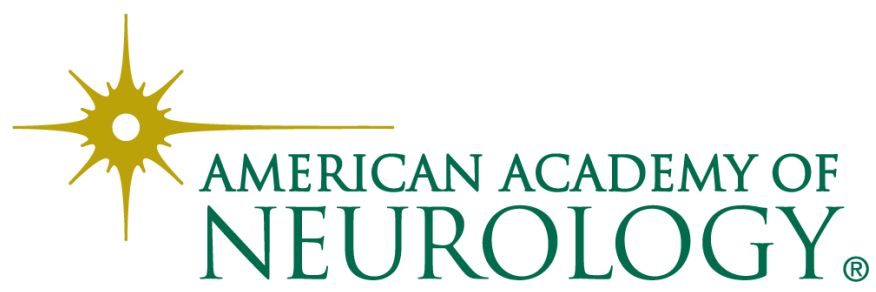

